гуманізації й гуманітаризації; наступності; науковості; свідомості й активності; системності, послідовності й раціональності; доступності й достатнього рівня складності; зв’язку теорії з практикою; професійно-педагогічної значущості знань; професійної компетентності; інтеграції.

\title{
Література
}

1. Большой энциклопедический словарь.-[2-е изд., перераб. и доп.]. - М. : Большая Российская энциклопедия; СПб. : Норинт, 2001. - 1456 с. 2. Борисова 3. Н. Метод научной педагогики М. Монтессори / 3. Н. Борисова, Р. А. Семерникова. - К. : Деловая Украина, 1993. - 131 с. 3. Дистервег А. Избранные педагогические сочинения / А. Дистервег. - М. : Знание, 1956. - 374 с. 4. Загальна психологія : [підручник]/ О. В. Скрипченко, Л. В. Долинська, 3. В. Огороднійчук та ін. - К. : Либідь, 2005. - 464 с. 5. Загвязинский В.И. Методология и методика дидактического исследования/ В. И. Загвязинский. - М. : Педагогика, 1982. - 160 с. $\quad$ 6. Кессиди Ф. Х. Сократ / Ф. Х. Кессиди. - СПб. : Алетейя, 2001. - 343 с. 7. Русова С. Вибрані педагогічні твори / Софія Русова; [за ред. Є. І. Коваленко]. - К. : Либідь, 1997. - 320 с. 8. Философский энциклопедический словарь / [гл. ред.: Л. Ф. Ильичёв, П. Н. Федосеев, С. М. Ковалёв и др.]. - М. : Сов. энциклопедия, 1983. - 840 с. 9. Фіцула М. М. Педагогіка: [посібник] / Михайло Михайлович Фіцула. - К. : ВЦ «Академія», 2000. - 542 с.

\section{ІНДИВІДУАЛІЗАЦІЯ САМОСТІЙНОЇ НАВЧАЛЬНО-ПІЗНАВАЛЬНОЇ ДІЯЛЬНОСТІ СТУДЕНТІВ ВИЩИХ ТЕХНІЧНИХ НАВЧАЛЬНИХ ЗАКЛАДІВ ЯК АКТУАЛЬНА ДИДАКТИЧНА ПРОБЛЕМА}

Бугра А. В. Індивідуалізація самостійної навчально-пізнавальної діяльності студентів вищих технічних навчальних закладів як актуальна дидактична проблема.

У статті здійснюється оглядовий аналіз еволюції педагогічних поглядів на проблему індивідуалізації навчання, обгрунтовується необхідність розроблення дидактичних засад реалізації принципу індивідуально-диференційованого підходу до студентів у процесі їх самостійної навчально-пізнавальної діяльності.

Ключові слова: самостійна навчально-пізнавальна діяльність, індивідуалізація, диференціація, індивідуально-диференційований підхід.

Бугра А. В. Индивидуализация самостоятельной учебно-познавательной деятельности студентов высших технических учебных заведений как актуальная дидактическая проблема.

В статье осуществлен обзорный анализ эволюции педагогических взглядов на проблему индивидуализации обучения, обосновывается необходимость разработки дидактических основ реализации принципа индивидуально-дифференцированного подхода к студентам в процессе их самостоятельной учебно-познавательной деятельности.

Ключевые слова: самостоятельная учебно-познавательная деятельность, индивидуализация, дифференциация, индивидуально-дифференцированный подход.

Bugra A. V. Personalization independent teaching and learning of high school students as relevant didactic problem.

The article presents a review of the evolution of pedagogical views on the problem of individualization of learning, the necessity of developing didactic framework of the principle 
of individual and differentiated approach to the students in the process of self-learning and cognitive activity.

Key words: self-training and cognitive activity, personalization, differentiation, individual and differentiated approach.

Кардинальні соціально-економічні реформації початку третього тисячоліття актуалізували в Україні нові вимоги до змісту й організації навчально-виховного процесу у вищій школі. Так, на підгрунті нової стратегічної програми європейської співпраці в галузі освіти і навчання «Освіта і навчання - 2020» в нашій державі започатковано реалізацію «Національної стратегії розвитку освіти в Україні на період до 2021 року», яка пріоритетним визначає підвищення якості навчання i, зокрема, організації самостійної навчально-пізнавальної діяльності студентів вищих навчальних закладів [1].

Невипадково, що проблема самостійної навчальної діяльності у зв’язку з іiі специфікою була й залишається в центрі дослідницької уваги, адже ще Я. Коменський на титульному аркуші знаменитої «Великої дидактики» написав: «Альфою й омегою нашої дидактики нехай буде пошук і відкриття способу, за якого б учителі менше навчали, а учні б більше вчилися». Геніальний фізик А. Ейнштейн лаконічно сформулював основний принцип самоосвіти: «Нічому не можна навчити, можна тільки навчитися».

Протягом останніх десятиліть організація самостійної роботи студентів (СРС) вищих навчальних закладів була предметом об'ємних комплексних науковопедагогічних досліджень. Проблеми пошуку ефективності форм і методів організації самостійної роботи вивчали М. Буланова-Топоркова, В. Буряк, О. Коновал, О. Малихін та ін. На теоретико-методологічному рівні визначено сутність самостійної роботи студента як активної пізнавальної діяльності суб'єкта навчання, яка набуває для нього особистого сенсу i здійснюється в аудиторний та позааудиторний час задля самостійного засвоєння необхідних для майбутньої професійної діяльності знань, умінь і навичок, здійснюється як під керівництвом викладача, так і без його безпосередньої участі та сприяє формуванню у студента такої особистісної риси, як самостійність. Самостійна навчальна робота вимагає від студента внутрішньої готовності до напруженої розумової та практичної діяльності у процесі оволодіння знаннями, уміннями і навичками. Погоджуємося з думкою з О. Пінської, яка стверджує, що поза самостійною роботою неможливо сформувати активну особистість і підготувати спеціаліста, який може швидко адаптуватися до умов, що постійно змінюються [11, с. 81]. Дидактичні особливості самостійної роботи 3 акцентом на формування особистості творчого, конкурентоспроможного фахівця з вищою освітою, майбутнього вчителя, здібного до інноваційної професійної діяльності, спричиняють зростання дослідницького інтересу до проблематики вдосконалення професійнопедагогічної самоосвітньої діяльності. Так, за даними Т. Фіногєєвої [15], яка використовувала бібліотечні фонди та ресурси мережі Internet, в 1966-2009 p.p. захищено 127 кандидатських дисертацій, у яких досліджувалися питання, пов’язані з:

- різними аспектами розвитку пізнавальної самостійності та самостійної пізнавальної діяльності (32 дисертаціі);

- організацією самостійної роботи як засобу розвитку пізнавальної самостійності (35 дисертацій);

- удосконаленням організації самостійної роботи студентів (12 дисертацій);

- особливостями процесу самостійного навчання в інженерно-педагогічних навчальних закладах (13), під час вивчення психолого-педагогічних дисциплін (6), під час вивчення педагогічних дисциплін (5 дисертацій). 
В останні роки дослідницька увага до проблематики самоосвіти ще більше посилилася.

Критично-конструктивний аналіз досить об’ ємного масиву науково-педагогічних досліджень засвідчує, що попри значну увагу науковців до означеної проблеми, питання індивідуалізації самостійної роботи студентів на засадах диференційованого підходу в навчальному процесі ВН3 не знайшли достатнього висвітлення. Цей факт вимагає розв'язання об'єктивних суперечностей:

- між зростаючими викликами сучасності до сформованої самостійності як необхідної професійно-особистісної якості майбутнього педагога та наявною орієнтацією навчального процесу у вищій школі на «колективно-масові» форми i методи організації самостійної роботи студентів, що не враховує їх індивідуальних когнітивних програм, особистісних мотивів та сенсів;

- між попитом в українському суспільстві на фахівців-професіоналів, здатних до постійної самоосвіти (навчання протягом життя), оновлення на цих засадах змісту, форм i прийомів професійної діяльності, використання новітніх наукових досягнень, виявлення професійного динамізму та мобільності, та превалюванням у вищій школі традиційних підходів до організації самостійної роботи студентів, які продукують консерватизм у навчальній діяльності, стереотипність та ригідність професійного мислення;

- між декларованим студенту правом свободи вибору форм і методів самостійної роботи відповідно до стандартів Болонських угод і принципів кредитно-модульної системи навчання та недосконалістю дидактичних можливостей і засобів самостійної навчально-пізнавальної діяльності;

- між потребами практики у використанні диференційованої самостійної роботи студентів та недостатнім володінням викладачами дидактичними засадами індивідуалізації навчального процесу.

У зв'язку з викладеним вище метою статmі є обгрунтування необхідності індивідуалізації процесу самостійної роботи студентів ВТНЗ на основі індивідуальнодиференційованого підходу.

Зазначимо, що вимога врахування індивідуально-психологічних особливостей особистості в навчальному процесі має глибокі історичні корені. Так, ще при індивідуальному навчанні, яке превалювало в школах давнього світу і середньовіччя, педагоги помітили, що учні по-різному сприймають і засвоюють навчальний матеріал. У відомому трактаті «Про виховання оратора» Марк Фабій Квінтілліан дає пораду вихователям «пізнавати властивості розуму і характеру учня» [8, с. 44]. Зародження класно-урочної системи навчання, яка на той час мала прогресивний характер, поглибило виникле протиріччя між колективними формами навчання та індивідуальним характером засвоєння знань. Невипадково «вчитель німецьких учителів» А. Дістервег лаконічно формулює вагому педагогічну аксіому «Ураховуй індивідуальність своїх учнів» [6, с. 419].

Не вважаючи за можливе в межах пропонованої статті висвітлити повну еволюцію поглядів на проблему індивідуалізації навчання, підкреслимо, що іiі становлення відбувалося шляхом переходу від простих рекомендацій ураховувати індивідуальні особливості учнів до виокремлення цих порад у відповідний дидактичний принцип. На наш погляд, принциповим історико-педагогічним моментом у цьому відношенні можна вважати публікацію К. Федоровського «Індивідуальний підхід до учня в радянській школі», у якій автор визначає індивідуальний підхід як педагогічний принцип, що пронизує всю діяльність педагога, визначає його ставлення до дітей, спрямовує свідомість педагога на особистість учня, запобігає в діяльності педагога формальному, 
бездумному ставленню до дітей як до однорідної маси, а до окремого учня як до математичної одиниці, математичного середнього [14].

У 70-ті роки минулого століття науково-педагогічні дискусії загострилися навколо 3’ясування сутності дефініцій «індивідуалізація», «диференціація», «індивідуальнопсихологічні особливості», «типологічні особливості», «дидактичне диференціювання» тощо.

Так, у словнику іншомовних слів визначено: «Індивідуалізація (лат. induviduum неподільне, особа) - прийняття до уваги особливостей кожного індивідума» [12, с. 192]. Проблема індивідуалізації навчання актуалізувала низку питань дидактичної спрямованості, зокрема, дискутувалося, що під час організації індивідуальної навчальної діяльності слід: а) ураховувати окремі індивідуально-психологічні риси суб'єкта навчання; б) ураховувати комплекс індивідуально-психологічних рис особистості, серед яких найчастіше пропонувалося враховувати розумові здібності, інтерес до навчання та рівень знань [5, с. 13]; в) визначати реальні перспективи врахування у процесі навчання виявлених рис особистості та методи індивідуалізації навчання.

Пошук відповідей на ці запитання дозволив дійти до усвідомлення необхідності врахування в навчальному процесі як суто індивідуальних особливостей учня чи студента, так і тих особливостей, які є спільними для деяких груп суб'єктів навчання. Зважаючи на ці реалії, у педагогіці почали використовувати поняття «індивідуальнопсихологічні» та «індивідуально-типові» особливості особистості $[9$, с. 8]. Об'єднання суб'єктів навчання в окремі групи на засадах урахування їх типологічних особливостей отримало назву індивідуальної типології, а розподіл учнів чи студентів за цими групами задля навчання за програмою певного рівня складності почали характеризувати як типологічну класифікацію або дидактичне диференціювання [13; 17; 19 та ін.] (від differentio (лат. - відмінність)) - розподіл, роз'єднання, розшарування цілого на частини, форми, ступені [12, с. 171]. На нашу думку, найбільш чітке обгрунтування сутності внутрішньої (в класі, групі) диференціації було запропоноване А. Кірсановим, який розглядав диференційований підхід як особливий підхід вчителя до різних груп учнів чи окремих учнів, що полягає в організації навчальної роботи, різної за змістом, обсягом, складністю, методами та прийомами $[9$, с. 35 ; 10]. Розглядаючи індивідуалізацію як знання та врахування індивідуальних неповторних рис особистості, а диференціацію як розподіл класу на якісно різні частини - типологічні групи, що об'єднують суб'єктів навчання на основі типових (повторюваних, схожих) властивостей для організації навчальної роботи, яке вирізняється змістом, обсягом, темпом, складністю виконуваних завдань, Т. Туркот пропонує розглядати єдність цих тенденцій як індивідуальнодиференційований підхід [13, с. 31]. Важливо, що в науково-педагогічних розвідках 7090-х років дослідники підкреслюють необхідність диференційованого підходу на кожному етапі навчання $[2 ; 3 ; 4 ; 13 ; 16 ; 17$ та ін.]. Зокрема, Ю. Бабанський стверджує: «Головним полем диференціації $є$ різноманітні форми самостійної роботи учнів щодо закріплення, поглиблення й систематизації знань як на уроці, так і особливо під час домашньої роботи» [3, с. 116]. Ця теза залишається актуальною і нині як для дидактики середньої, так i для дидактики вищої школи. Так, О. Пінська підкреслює, що диференційований підхід у процесі організації самостійної роботи дає можливість усунути перенавантаження студентів, позбавити комплексу «середнього студента», своєчасно виявити прогалини в знаннях і окреслити шляхи їх ліквідації, забезпечити засвоєння програмного матеріалу менш підготовленими і сприяє розвитку більш підготовлених, розвиває їх пізнавальні інтереси, творчу ініціативу, сприяє створенню умов для визначення найдоцільнішого режиму навчальної роботи 3 кожним, дозволяє 
раціонально завантажувати їх самостійною роботою, ураховуючи індивідуальні особливості [11, с. 82].

Досліджуючи дидактичні засади формування індивідуально-особистісного стилю пізнавальної діяльності студентів вищих педагогічних навчальних закладів, І. Дорохіна доходить висновку, що індивідуалізація та диференціація навчання у вищій школі сприяють розвитку самостійності в навчальній роботі студентів, різних за рівнем успішності й загальнокультурним розвитком, - кожен студент працює напружено й у такому темпі, який відповідає його індивідуальним можливостям, привчаючись до щоденної самостійної праці. У дисертаційному дослідженні І. Дорохіна пропонує варіанти диференціації та індивідуалізації пізнавальної діяльності з урахуванням працездатності, здібностей до навчання, успішності та пізнавальної самостійності студентів [7, с. 9-10]. Ми погоджуємося з точкою зору дослідників [7; 11; 13; 18], згідно 3 якою для ефективної різнорівневої самостійної роботи суб'єктів навчання першочерговою постає потреба наукового обгрунтування критеріїв, за якими буде здійснюватися диференціація завдань для самостійної роботи, пропонованих динамічним різнорівневим групам.

Підсумовуючи, зауважимо, що проблема індивідуалізації СРС є об'ємною та різноплановою, а тому перспективу наших подальших наукових розвідок ми вбачаємо насамперед у виявленні психолого-педагогічної сутності дидактичного диференціювання, розробленні варіативно-дидактичної моделі організації різнорівневої самостійної роботи студентів відповідно особливостей їх навчально-пізнавальної діяльності, а також експериментальній перевірці ефективності пропонованої моделі в умовах кредитно-модульної системи навчання в сучасному ВТНЗ.

\section{Література}

1. Національна стратегія розвитку освіти в Україні на період до 2021 року/ [Електронний ресурс] // Урядовий кур'єр. - 2013. - № 117. - (04 липня). - С. 11-13. Режим доступу: www.ukurier.gov.ua. 2. Александров П. Индивидуализация обучения / П. Александров // Народна просвета. - 1975. - № 6. - С. 65-73. 3. Бабанский Ю. К. Методика преподавания физики в средней школе. Общетеоретические вопросы : учеб.метод. пособ. для студ. пед. ин-тов / Ю. К. Бабанский. - М. : Просвещение, 1968. - 199 с. 4. Галузинский В. М. Индивидуальный подход в воспитании учащихся/ В. М. Галузинский. - К. : Рад. школа, 1982. - 132 с. 5. Гуревич К. М. Индивидуальнопсихологические особенности учащихся / К. М. Гуревич. - М. : Знание, 1988. - 80 с. 6. Дистервег А. Руководство к образованию немецких учителей/ А. Дистервег// Хрестоматия по истории зарубежной педагогики / сост.: А. И. Пискунов. - [2-е изд. перераб.]. - М. : Просвещение, 1971. - С. 385 -444. 7. Дорохіна I. В. Дидактичні засади формування індивідуально-особистісного стилю пізнавальної діяльності студентів вищих педагогічних навчальних закладів: автореф. дис. на здобуття наук. ступеня канд. пед. наук : спец. 13.00.09 «Теорія навчання» / Дорохіна Ірина Василівна. - Кривий Ріг, 2012. - 21 с. 8. Квинтиллиан М. Ф. О воспитании оратора // Хрестоматия по истории зарубежной педагогики / сост.: А. И. Пискунов. - [2-е изд., перераб.]. - М. : Просвещение, 1971. - С. 39-45. 9. Кирсанов А. А. Индивидуализация учебной деятельности как педагогическая проблема / А. А. Кирсанов. - Казань : Изд-во Казан. ун-та, 1988. - 224 с. 10. Кирсанов А. А. К вопросу о социальных психологопедагогических основах индивидуализации и дифференциации учебной деятельности школьников / А. А. Кирсанов // Воспитание познавательной активности школьников. Казань, 1975. - С. 112-162. 11. Пінська О. Л. Диференціація самостійної роботи студентів як психолого-педагогічна проблема / О. Л. Пінська // Матеріали міжнародної науково-технічної конференції «Сталий розвиток промисловості та суспільства», 
(Кривий Ріг, 22 -25 травня 2013р.) ; в 2-х томах. - Кривий Ріг : Копіювальний центр КПІ ДВНЗ «КНУ», 2013. - Т. 2. - С. 81-84. 12. Словарь иностранных слов. - [9-е изд., испр.]. - М. : $\quad$ Рус. язык, 1982. - 608 с. $\quad$ 13. Туркот Т. И. Индивидуальнодифференцированный подход к учащимся при систематическом повторении курса физики (X-XI кл.) : дис. ... канд. пед. наук : 13.00.02 / Туркот Тетяна Іванівна. - К., 1992. - 219 с. 14. Федоровский К. Т. Индивидуальный подход к учащимся в советской школе / К. Т. Федоровский // Сов. Педагогіка. - 1937. - №3. - С. 117-132. 15. Фіногєєва Т. С. Організація самостійної роботи майбутніх інженерів-педагогів у процесі вивчення педагогічних дисциплін : дис.... канд. пед. наук : 13.00.09 / Фіногєєва Тетяна Свгенівна. - Луганськ, 2011. - 334 с. 16. Хлебникова И. В. Об индивидуальном подходе в обучении и воспитании и современность / И. В. Хлебникова, Б. Г. Ананьев // Психолого-педагогическое обеспечение учебного процесса. - М. , 1987. - С. 151-156. 17. Чередов И. М. О дифференцированном обучении на уроках / И. М. Чередов. Омск : Зап. Сиб. кн. изд-во, 1973. - 155 с. 18. Ярошенко О. Г. Порівняльний аналіз стилів навчання студентів різних спеціальностей / О. Г. Ярошенко, Т. М. Деркач// Педагогіка і психологія. - 2012. - №1. - С. 43-47. 19. Hoffmann K.-I. Möglichkeiten der didaktischen Differenzierung im Physikunterricht // Physik in der schule. - 1978. - №7-8. S. 311-317.

\section{АНАЛІЗ РЕЗУЛЬТАТІВ УПРОВАДЖЕННЯ ДИДАКТИЧНОЇ МОДЕЛІ ФОРМУВАННЯ ПІЗНАВАЛЬНОЇ САМОСТІЙНОСТІ СТУДЕНТІВ НЕМОВНИХ СПЕЦАЛЬНОСТЕЙ У ПРОЦЕСІ ВИВЧЕННЯ ІНОЗЕМНИХ МОВ}

Довганець В. І. Аналіз результатів упровадження дидактичної моделі формування пізнавальної самостійності студентів немовних спеціальностей у процесі вивчення іноземних мов.

У статті представлено шляхи реалізації дидактичної моделі формування пізнавальної самостійності студентів немовних спеціальностей у процесі вивчення іноземних мов. Автор аналізує результати впровадження дидактичної моделі, отримані через емпіричне дослідження об'єкта, i відтворює якісно-кількісну динаміку формування пізнавальної самостійності студентів за обраними критеріями.

Ключові слова: дидактична модель, пізнавальна самостійність, вивчення іноземних мов, шляхи реалізації, результати впровадження.

Довганец В. И. Анализ результатов внедрения дидактической модели формирования познавательной самостоятельности студентов неязыковых специальностей в процессе изучения иностранных языков.

В статье представлены пути реализации дидактической модели формирования познавательной самостоятельности студентов неязыковых специальностей в процессе изучения иностранных языков. Автор анализирует результаты внедрения дидактической модели, полученные через эмпирическое исследование объекта, и представляет качественно-количественную динамику формирования познавательной самостоятельности студентов по выбранным критериям.

Ключевые слова: дидактическая модель, познавательная самостоятельность, изучение иностранных языков, пути реализации, результаты внедрения. 